RASĀYAN J. Chem.

Vol. 12 | No. 2 |780 - 786| April - June | 2019

ISSN: 0974-1496 | e-ISSN: 0976-0083 | CODEN: RJCABP

http://www.rasayanjournal.com

http://www.rasayanjournal.co.in

\title{
CHARACTERIZATION OF MEMBRANE PVA-ENZYME COATED PVC-KTpCIPB AS UREA SENSOR WITH POTENTIOMETRIC METHOD
}

\author{
A. Hakim S. ${ }^{1, *}$, T. Sembiring ${ }^{2}$, K. Tarigan ${ }^{2}$, K. Sebayang ${ }^{2}$, M. Situmorang ${ }^{3}$ \\ and N. M. Noer ${ }^{2}$ \\ ${ }^{1}$ Department of Physics, Universitas Negeri Medan, Jl. William Iskandar Pasar V, \\ Medan 20211, Indonesia \\ ${ }^{2}$ Department of Physics, Universitas Sumatera Utara, Jl. Bioteknologi No. 1., \\ Medan 20155, Indonesia \\ ${ }^{3}$ Department of Chemistry, Universitas Negeri Medan, Jl. William Iskandar Pasar V, \\ Medan 20211, Indonesia \\ *E-mail: abdhakims@unimed.ac.id
}

\begin{abstract}
Membranes with PVA, enzymes, and PVC-KTpCIPB contribute as pores on the indicator electrode of potentiometric cells to produce voltage. This study aimed to characterize membranes modified with PVA, enzymes, and PVC-KTpClPB as urea sensors. Membrane modification was done in three variations: membrane A (0.504 $\mathrm{g}$ of PVA, $0.504 \mathrm{~g}$ of PVC, $1 \mathrm{mg}$ of enzymes, and $0.012 \mathrm{~g}$ of KTpCIPB), membrane B (0.035 g of PVA, $0.035 \mathrm{~g}$ of PVC, $1 \mathrm{mg}$ of enzymes, and $0.012 \mathrm{~g}$ of KTpCIPB), and membrane C (0.035 g of PVA, $0.035 \mathrm{~g}$ of PVC, $1 \mathrm{mg}$ of enzymes, and $0.050 \mathrm{~g}$ of KTpCIPB). The analysis was performed using UV-Visible to obtain the best membranes, namely membrane $\mathrm{A}$ and $\mathrm{C}$. The preparation of electrodes was carried out using membrane $\mathrm{A}$ and $\mathrm{C}$ with various PVA coatings, such as one coating for membrane electrode $A_{1}$ and $C_{1}$, two coatings for membrane electrode $A_{2}$ and $C_{2}$, and three coatings for membrane electrode $\mathrm{A}_{3}$ and $\mathrm{C}_{3}$. XRD analysis was performed to obtain the best membrane electrode which was the membrane electrode $\mathrm{C}_{2}$. Based on the measurement analysis of electrode membrane in the potentiometric cells with electrochemical techniques, the sensitivity obtained was $19.069 \mathrm{mV} /$ decade with a confidence level of $\mathrm{R}^{2}=0.9434$ in the range of $1.10^{-5}-5.10^{-4} \mathrm{M}$ and detection limit of $1.10^{-5} \mathrm{M}$.

Keywords: PVA-enzyme, PVC-KTpClPB, Membrane Electrode, Potentiometric Cells, Urea Sensor, Sensitivity and Detection Limit.
\end{abstract}

(C) RASĀYAN. All rights reserved

\section{INTRODUCTION}

The selection of molecular recognition elements is a complex step in the construction of biosensor because most of the chemical sensors are selective for analytes involving the molecular recognition elements and transducers. As an example, proteins and enzymes are compounds that must be immobilized to be used as biosensors because they have unstable properties ${ }^{1}$. Several things that should be considered in developing a biosensor system include electrochemical characterization, such as response time, signal response reproducibility, recovery time, selectivity, stability, sensitivity, linear response, and operating time ${ }^{2}$.

Regarding the biosensor construction, conductive polymers can be used as a transducer which can help the conversion of biochemical signals into electronic signals in enzyme biosensors ${ }^{3,4}$. The integration of enzymes and polymer matrix is defined as entrapment whose matrix can act as a barrier in complex media, such as serum and food ${ }^{5}$. In this case, poly(vinyl alcohol) (PVA) and poly(vinyl chloride) (PVC) are polymers that can be used as electrode materials when redox activity occurs through oxidation process (doping $\mathrm{p}$ ) and reduction process (doping $\mathrm{n}$ ) for conduction ${ }^{6,7}$.

Rasayan J. Chem., 12(2), 780-786(2019)

http://dx.doi.org/10.31788/RJC.2019.1225143

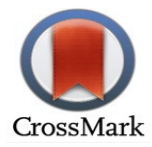


An example of a biosensor application is in the determination of urea levels in clinical, environmental, industrial, and food diagnostics. The potentiometric biosensor (PB) on ion-selective electrodes (ISE) is a method to determine urea analytes ${ }^{6}$. As mentioned above, the membrane modification using conductive polymers can be done with the PB method to improve the effectiveness of biosensors.

Based on the explanation above, this study aimed to produce and characterize biosensors that have been modified with conductive polymers as an analysis instrument of urea in blood serum using the PB indicator method ${ }^{8}$. The biosensor used in the study has ISE electrode membranes ${ }^{9}$ from tungsten ${ }^{10}$, which have been modified through enzyme immobilization in PVA coated with PVC-KTpCIPB and Ag/AgCl electrode as the reference electrode. Furthermore, the electrochemical method was used for analytic detection in the matrix variations. Buffers used in the study were thetris- $\mathrm{HCl}$ buffer and $\mathrm{KH}_{2} \mathrm{PO}_{4}$ phosphate buffer. The characterization of membranes and membrane electrodes was done using FTIR, UV-Vis, SEM-EDX, and XRD. The electrochemical characterization of urea sensors was done using the indicator electrode of tungsten (W) without ISE immobilization in the buffer, $\mathrm{KCl}$, enzyme, and urea solution whereas the electrochemical characterization of urea sensors from the indicator electrode immobilized with the modification of W I PVA Enzyme I PVC-KTpCIPB was carried out in the buffer, $\mathrm{KCl}$, and urea solution.

\section{Material and Methods \\ Materials}

The materials used in this study were the standard urea, enzyme EC 3.5.1.5 (Urease) U4002, 50-100 kU (kilo unit), tungsten (W) with a diameter of $1.0 \mathrm{~mm}$ as the indicator electrode, $\mathrm{RE}-5 \mathrm{~B} \mathrm{Ag} / \mathrm{AgCl} \mathrm{MF}-2052$ as the reference electrode, Phosphate Buffer $\left(\mathrm{KH}_{2} \mathrm{PO}_{4}\right)$, tris- $\mathrm{HCl}$ buffer, PVA [- $\left.\mathrm{CH}_{2} \mathrm{CHOH}-\right] \mathrm{n}$, PVC $\left(\mathrm{CH}_{2} \mathrm{CHCl}\right)$ n, potassium tetrakis 4-chlorophenyl borate $\left(\left(\mathrm{ClC}_{6} \mathrm{H}_{4}\right)_{4} \mathrm{BK}\right)$, Tetrahydrofuran $\left(\mathrm{C}_{4} \mathrm{H}_{8} \mathrm{O}\right)$, and $\mathrm{KCl}$.

\section{Methods}

The potentiometric cells consisted of a reference electrode $(\mathrm{Ag} / \mathrm{AgCl})$ and indicator electrodes (ionselective (ISE)). The indicator electrode was immobilized with PVA enzyme solution and coated with PVC-KTpCIPB.

Based on the previous research by Górski et al. (2007), plasticizers were added in the preparation of membrane electrodes ${ }^{11}$. Moreover, composition variations should be done to obtain the best absorption spectrum $^{12}$. In this case, there were three variations of $d$, such as membrane A, membrane $B$, and membrane $\mathrm{C}$ with various compositions shown in Table-1.

Table-1: Composition of Modification Membranes

\begin{tabular}{c|c|c|c|c}
\hline \multirow{2}{*}{ Membrane } & \multicolumn{4}{|c}{ Percent Composition w/w } \\
\cline { 2 - 5 } & PVA & Enzyme & PVC & Plasticizer (KTpClPB) \\
\hline A & 504 & 1 & 504 & 12 \\
\hline B & 35 & 1 & 35 & 12 \\
\hline C & 35 & 1 & 35 & 50 \\
\hline
\end{tabular}

Furthermore, membranes with the composition of $\mathrm{A}$ and $\mathrm{C}$ were used as the membrane and indicator electrode membrane. The tungsten (W) indicator electrodes were coated with the composition of membrane $\mathrm{A}$ and $\mathrm{C}$ in which the coating was performed once so that these electrodes were labeled as $\mathrm{A}_{1}$ and $\mathrm{C}_{1}$ electrodes. Similarly, the tungsten (W) $\mathrm{A}_{2}$ and $\mathrm{C}_{2}$ indicator electrodes were coated twice with PVA and enzymes and once with PVC-KTpClPB whereas the tungsten (W) $\mathrm{A}_{3}$ and $\mathrm{C}_{3}$ indicator electrodes were coated thrice with PVA solution and enzymes and once with PVC-KTpCIPB. These electrodes were then characterized using XRD, and the best results were used as the indicator electrode of the potentiometric cells.

The potentiometric cells which have been made were filled with $0.001 \mathrm{M}$ of phosphate buffer solution and $0.001 \mathrm{M}$ of $\mathrm{KCl}$ and stirred until homogeneous. The injection of urea solution was done with the 
concentrations of $0.1 \mathrm{M}, 0.01 \mathrm{M}, 0.05 \mathrm{M}, 0.001 \mathrm{M}, 0.005 \mathrm{M}, 0.0005 \mathrm{M}$, and $0.00001 \mathrm{M}$ to obtain the characterization of the calibration curve, sensitivity, detection limit, and linear range of potentiometric cells.

\section{Detection Method}

The initial characterization performed was the characterization of the electrode membrane $\mathrm{A}, \mathrm{B}$, and $\mathrm{C}$ which is shown in Table 1 using UV-Vis Ray-Leigh 1601, SEM Evo MA 10 Zeiss, and SEM Q150RES Quorum Coating. The best electrode membrane was used as the indicator electrode of $A_{1}, A_{2}, A_{3}, C_{1}, C_{2}$, and $\mathrm{C}_{3}$ which were analyzed using XRD-6100 Shimadzu so that the best electrode was obtained.

The best indicator electrode was used for the potentiometric cells. Figure 1 shows a series of testing instruments of the potentiometric cells. Voltage was measured by a potentiometer through Power Lab, and the software continued the information obtained from the Power Lab to the computer in the form of data and display signals by the urea response as an analyte in buffer solution mixed with $\mathrm{KCl}$.

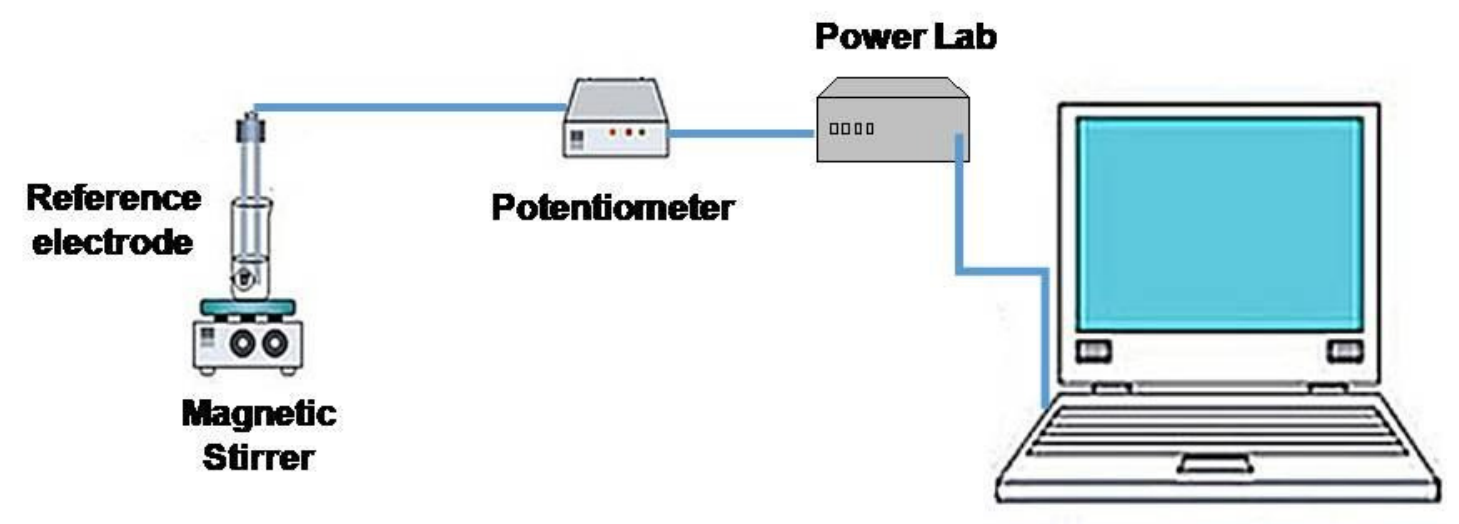

Fig.-1.Testing Instrumentation Series of Potentiometer Cells

Fourier Transform Infra Red (FTIR) Analysis

RESULTS AND DISCUSSION

PVA and PVC-KTpCIPB solutions were characterized using FTIR to analyze functional groups in both solutions. The FTIR spectrum can be seen in Figure 2.

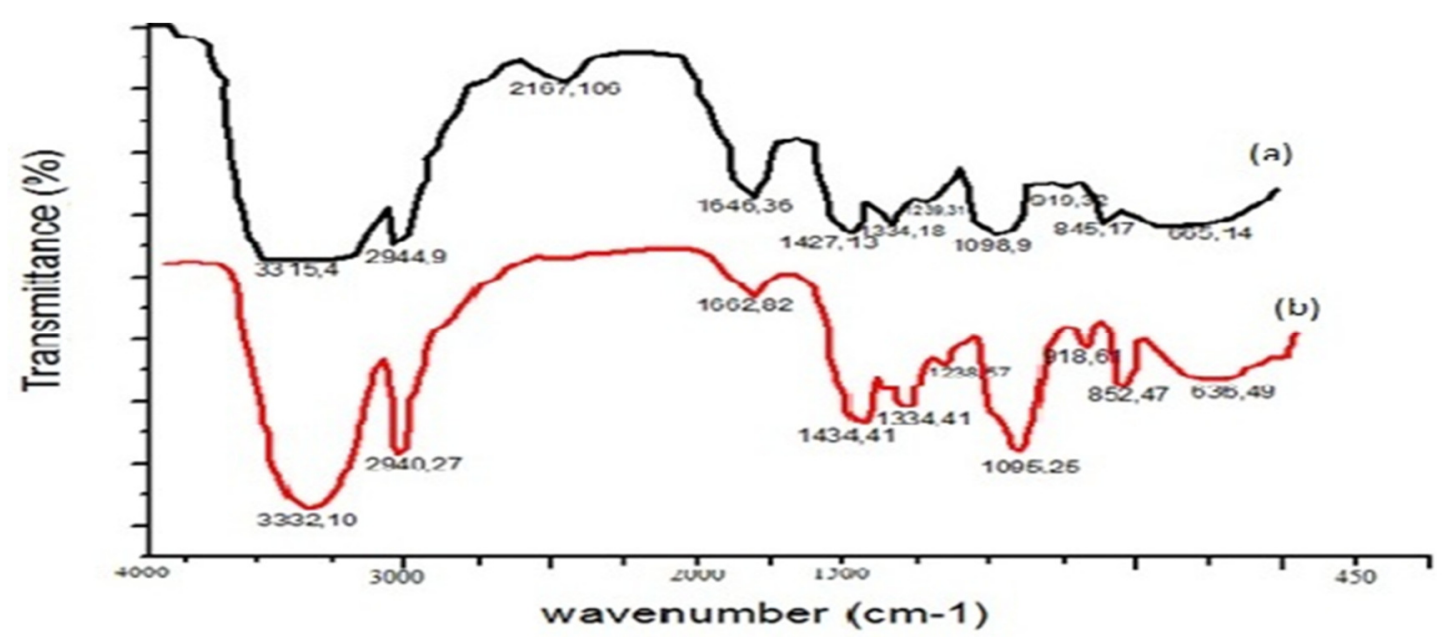

Fig.-2: FTIR Spectrum (a) PVA Solution, (b) PVC-KTpCIPB Solution

Based on Fig.-2, the $\mathrm{OH}$ and $\mathrm{CH}$ functional groups seen in the PVA and PVC-KTpCIPB solutions were at the wavenumbers of $2944.9 \mathrm{~cm}^{-1}, 919.32 \mathrm{~cm}^{-1}$, and $845.17 \mathrm{~cm}^{-1}$ and at the group of wavenumbers of 2700$3300 \mathrm{~cm}^{-1}$ and $700-950 \mathrm{~cm}^{-1}$.In contrast, the $\mathrm{C} \equiv \mathrm{C}$ functional group was only obtained in the PVA solution at the wavenumbers of $2167.106 \mathrm{~cm}^{-1}$ and at the group wavenumber of $2100-2200 \mathrm{~cm}^{-1}$. The 
functional groups obtained in both PVA and PVC-KTpCIPB solutions were the N-H functional group at the wavenumber of $3100-3400 \mathrm{~cm}^{-1}$, the C-O functional group at the wavenumbers of $1200-1350 \mathrm{~cm}^{-1}$, and the -cis functional group (entered the $\mathrm{C}-\mathrm{H}$ functional group) at the wavenumber of $650-800 \mathrm{~cm}^{-1}$. These results were in accordance with previous research which stated that there were covalent bonds of $\mathrm{CH}_{2}$ functional groups in PVA and $\mathrm{PVC}^{13}$.

\section{UV-Visible Spectroscopy Analysis}

The UV-Visible test results for membrane A, B, and C are shown in Fig.-3.

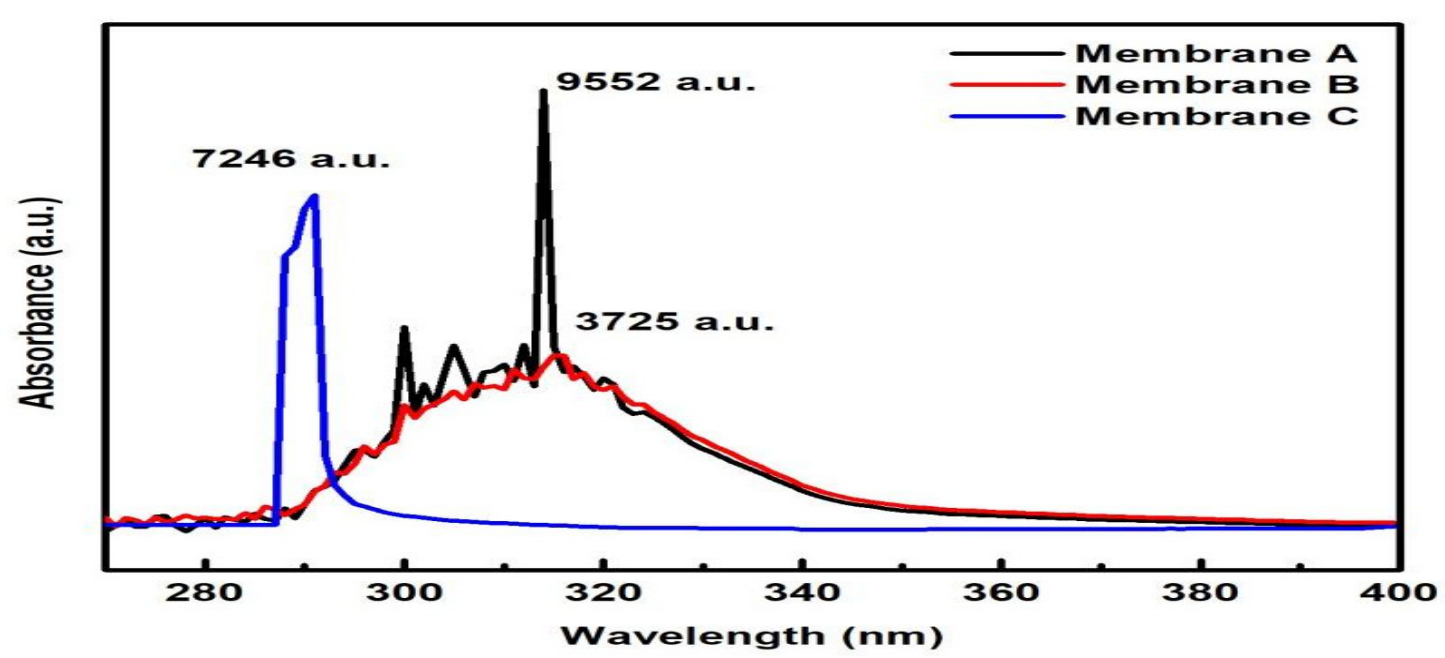

Fig.-3: UV-VIS Absorption Spectra of the Solution of Membrane A; Membrane B; and Membrane C.

Mohammadi et al. (2010) found that the ratio of plasticizers/PVC and additive properties used significantly would influence the sensitivity and selectivity of the ion-selective electrodes ${ }^{14}$. In Fig.-3, the difference in height and width of the absorbance peak against the wavelength was due to differences in the concentration ${ }^{15}$, namely: (a) membrane $\mathrm{A}$ at the wavelength of $314 \mathrm{~nm}$ with absorbance of 9.552 a.u.; (b) membrane $\mathrm{B}$ at the wavelength of $315 \mathrm{~nm}$ with absorbance of 3.725 a.u.; and (C) membrane $\mathrm{C}$ at the wavelength of $291 \mathrm{~nm}$ with absorbance of 7.246 a.u.

\section{X-Ray Diffraction (XRD) Analysis}

Figure 4 shows the XRD diffraction patterns from membrane $A$, membrane $C$, electrode $A_{3}$, and electrode $\mathrm{C}_{2}$. The selection of membrane and electrode variations was done because membrane $\mathrm{A}$ and $\mathrm{C}$ gave the best results based on the UV-Visible results. The X-ray diffraction patterns can be used to determine the best membrane/electrode membrane in PVA-Enzyme coated PVC-KTpClPB ${ }^{16}$.

Figure-4 shows that: membrane A had diffraction peaks at $2 \theta=22.62 \square, 28.66 \square, 32.66 \square, 44.56 \square$, and $64.86 \square$; membrane $\mathrm{C}$ had diffraction peaks at $2 \theta=22.62 \square, 28.66 \square, 32.70 \square, 44.54 \square$, and $64.88 \square$; electrode $\mathrm{A}_{3}$ had diffraction peaks at $2 \theta=21.76 \square, 28.68 \square, 32.68 \square, 44.54 \square$, and $64.84 \square$; and electrode $\mathrm{C}_{2}$ had diffraction peaks at $2 \theta=22.24 \square, 22.62 \square, 28.62 \square, 32.62 \square, 44.52 \square$, and $64.84 \square$.

Based on Fig.-4, membrane A showed the highest peak at $2 \theta=44.54 \square$ (6570 a.u.) whereas the highest peak of the electrode membrane $\left(\mathrm{A}_{3}\right)$ was at $2 \theta=44.52 \square$ (3904 a.u.) in which the peak intensity decreased after the electrode membrane was formed. On the other hand, membrane $\mathrm{C}$ showed the highest peak at $2 \theta=44.56 \square$ (6162a.u.), whereas the highest peak of the electrode membrane $\left(\mathrm{C}_{2}\right)$ was at $2 \theta=$ $44.52 \square$ (6306 a.u.) in which the peak intensity increased after the electrode was immobilized by the membrane. It shows that the best electrode membrane was the electrode membrane $\mathrm{C}_{2}$.

\section{Scanning Electron Microscopy (SEM) Analysis}

The composition of PVC-KTpCIPB influences the morphology of the membrane in the enzyme PVA, especially in the clearly visible pores with the observation diameter of $2 \mu \mathrm{m}$. The thickness of the layer of the membrane C's coating determines SEM morphology and PVC properties ${ }^{17}$. This is shown in Fig.-5. 


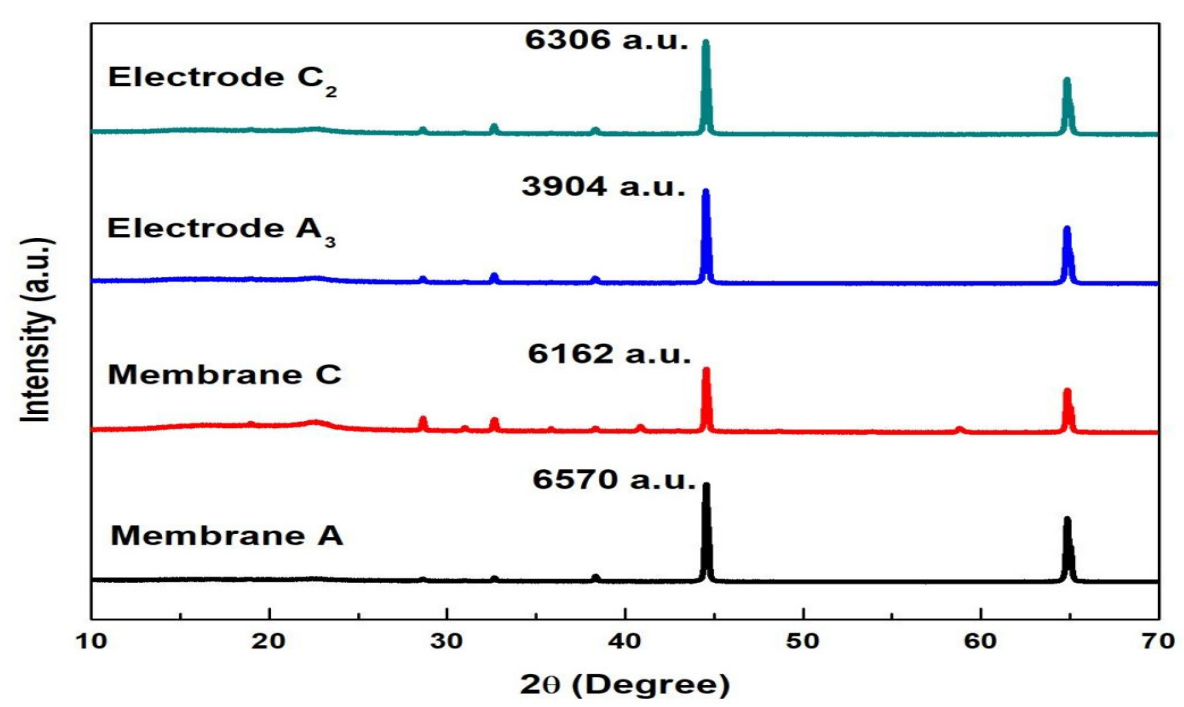

Fig.-4: XRD Diffraction Patterns of Membrane A; Membrane C; Electrode $\mathrm{A}_{3}$; and Electrode $\mathrm{C}_{2}$

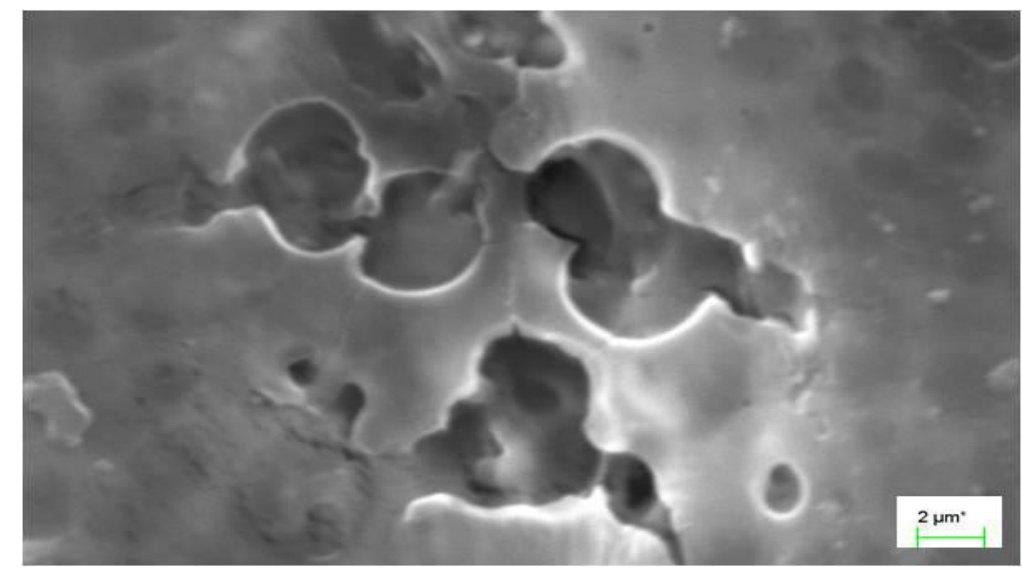

Fig.-5: Scanning Electron Microscopic Image of Membrane C with 10000x Magnifications.

\section{Calibration Curve Urea from ISE on Immobilized Indicator Electrodes}

The potential calculation of ISE biosensors was using the formula $(1)^{18}$.

$$
E_{\text {cell }}=E_{\text {cons }}+S \log \log C
$$

$\triangle \mathrm{E}$ voltage response of ISE urea biosensor was changed using equation (2) and (3).

$$
\begin{aligned}
& E_{\text {cell }}-E_{\text {cons }}=S \log \log C \\
\Delta E & =S \log \log C
\end{aligned}
$$

The calibration curves were made in the logarithm of concentration in molar (M) to voltage potentiometer by Chey et al. (2012) and concentration of potentiometer voltage by Mishra et al. (2014) whereas Ismail \&Adeloju (2010) explained calibration curves in log concentration in $\mathrm{pH}$ to potentiometer voltage ${ }^{19-21}$. The voltage between peak oxidation and reduction is theoretically $59 \mathrm{mV}$ (reversible reaction) whereas in practice this value varies in the range of $70-100 \mathrm{mV}$. A voltage greater than $100 \mathrm{mV}$ or the presence of oxidation peak and non-symmetrical reduction are indications of the presence of irreversible reaction. Based on the analysis of the electrode sensor calibration curve, the sensitivity of the electrode was 19.069 $\mathrm{mV} /$ decade in the range of $1.10^{-5}-5 \cdot 10^{-4} \mathrm{M}$ at the detection limit of $1.10^{-5} \mathrm{M}$. As shown in Figure 6, this value is consistent with previous studies which stated that PVC electrode membrane had sensitivity of $19.7 \mathrm{mV} /$ decade in the range of $5.10^{-7}-10^{-2} \mathrm{M}^{22}$. The sensitivity values vary depending on the range and detection limit ${ }^{23,24}$. Several studies reported that electrode membranes had a sensitivity of $57 \mathrm{mV} / \mathrm{dec}$ ade (for PVC-NPOE) and sensitivity of $58.59 \mathrm{mV} / \mathrm{dec}$ ) (for PVC-tricressyl phosphate TCPhexadecylmethylbenzylammonium HDTMA + polystyrene (PS-) for potentiometric titration ${ }^{25}$. 


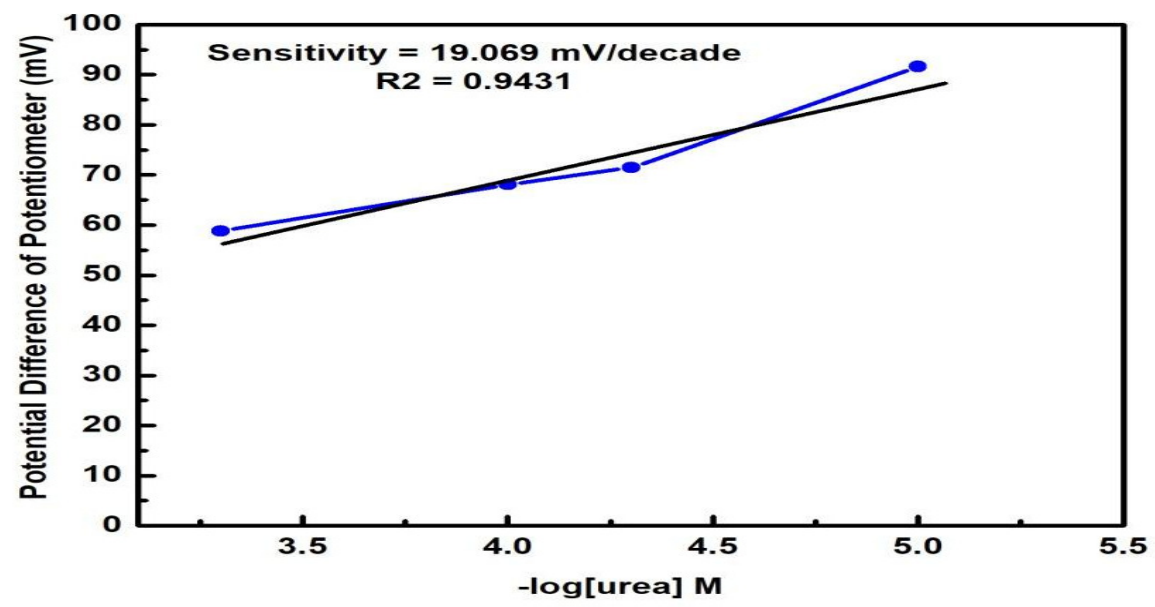

Fig.-6: Calibration Curve of Urea Sensor of ISE-Urea with Potentiometric Systems using Membrane Electrode $\mathrm{C}_{2}$.

The composition and slope of calibration curves are influenced by the plasticizer, dielectric constant, and load exchange mobility. These aspects also determine the characteristics of electrodes ${ }^{26}$. In this study, there was no variation in the composition and variations of plasticizer and the dielectric constant in order to obtain the best calibration curve. The linear range was, therefore, determined based on the concentration, sensitivity, enzyme concentration, and $\mathrm{pH}$ buffer $^{21}$. In this regard, this study found a correlation coefficient $\mathrm{R}^{2}=0.9431$ which can be seen in Fig.-6. According to Mwangi et al. (2012), absorbance is influenced by the concentration range, height, and width of the peak, and the linear curve. Based on Mwangi et al. (2012), a small concentration range of $1.95 \cdot 10^{-4}-3.51 .10^{-3} \mathrm{M}$ would form a linear curve with a large confidence level of $\mathrm{R}^{2}$ whereas a large concentration range of $1.95 .10^{-4}-4.88 .10^{-2}$ $M$ would form a linear curve with a small confidence level of $R^{227}$. This can be seen in Figure 6 and 3 for membrane $\mathrm{C}$.

\section{CONCLUSION}

The characterization of electrode membranes was carried out in two stages which were material and electrochemical characterization. FTIR analysis showed that the PVA and PVC-KTpCIPB solutions used in this study had functional groups that corresponded to the standards, namely the O-H, C-H, N-H, C-O, and -cis functional groups (entered the $\mathrm{C}-\mathrm{H}$ functional group). Characterization through $\mathrm{UV}-\mathrm{V}$ is showed that the best membranes were membrane A $(0.504 \mathrm{~g}$ of PVA, $0.504 \mathrm{~g}$ of PVC, $1 \mathrm{mg}$ of enzymes, and $0.012 \mathrm{~g}$ of KTpCIPB) and membrane C (0.035 $\mathrm{g}$ of PVA, $0.035 \mathrm{~g}$ of PVC, $1 \mathrm{mg}$ of enzymes, and $0.050 \mathrm{~g}$ of $\mathrm{KTpCIPB}$ ). Based on the XRD analysis results, the best electrode membrane was the electrode membrane $\mathrm{C}_{2}$ which used membrane $\mathrm{C}$ composition and experienced twice coating. The characterization of electrode membranes in potentiometric cells by electrochemical techniques provided a linear curve with a level of confidence. It showed that the preparation of urea sensors from ISE with modified indicator electrodes using PVA and PVC-KTpClPB with suitable compositions would increase absorbance if KTpCIPB reduced the absorbance.

\section{ACKNOWLEDGMENT}

The authors would like to thank the Physics and Chemistry Laboratory of the Universitas Sumatera Utara and Universitas Negeri Medan for their assistance in developing scientific materials, especially the polymer-based sensors.

\section{REFERENCES}

1. A. M. Gonçalveset al., Molecules, 19, 12461(2014), DOI: 10.3390/molecules190812461

2. M. S. Thakur \& K. V. Ragavan, Journal of Food Science and Technology, 50, 625-641 (2013), DOI: 10.1007/s13197-012-0783-Z

3. C. Y. Lai, P. J. S. Foot, J. W. Brown \& P. Spearman, Biosensors, 7, (2017), DOI: 10.3390/bios 7010013

4. H. Darmokoesoemoet al.. Rasayan J. Chem.7, 54(2017), DOI: 10.1016/j.rinp.2017.05.013 
RASĀYAN J. Chem.

Vol. 12 | No. 2 |780 - 786| April - June | 2019

5. G. Hughes et al., Biosensors, 6, (2016), DOI: 10.3390/bios6040050

6. E. Jaworska, K. Maksymiuk\& A. Michalska, Chemosensors, 3, 200(2015), DOI: 10.3390/chemosensors3030200

7. S. K. ShahenoorBashaet al.. Rasayan J. Chem.10, 1159(2017).

8. A. Mathuret al., PLoS One, 8, (2013), DOI: 10.1371/journal.pone.0057681

9. A. R. Barbosa \& A. Karmali, Biocatal. Biotransformation, 29, 130(2011), DOI: 10.3109/10242422.2011.591926

10. D. Schönauer-Kamin, M. Fleischer \& R. Moos, Sensors (Switzerland), 13, 4760(2013), DOI: 10.3390/s130404760

11. Ł. Górski, D. Klimaszewska, M. Pietrzak\& E. Malinowska, Anal. Bioanal. Chem., 389, 533(2007), DOI: $10.1007 / \mathrm{s} 00216-007-1469-7$

12. M. Rezayiet al., Sensors (Switzerland), 12, 8806(2012), DOI: 10.3390/s120708806

13. F. Karim \& A. N. M. Fakhruddin, 11, 261(2012), DOI: 10.1007/s11157-012-9268-9

14. M. Mohammadi, M. Khodadadian\& M. K. Rofouei, Collect. Czechoslov. Chem. Commun., 75, 563(2010), DOI: $10.1135 / \operatorname{ccc} 2009555$

15. S. Z. Mohammadi, H. Beitollahi\& E. BaniAsadi, Environ. Monit. Assess., 187, (2015), DOI: 10.1007/s10661-015-4309-9

16. S. Mignardi, A. Corami\& V. Ferrini, Water. Air. Soil Pollut., 224, (2013), DOI: 10.1007/s11270013-1447-y

17. S. Yamada, A. Yamamoto \& T. P. Kasuga, J. Mater. Sci. Mater. Med., 25, 2639(2014), DOI: 10.1007/s10856-014-5302-5

18. A. A. Ismaiel, M. K. Aroua\& R. Yusoff, Sensors (Switzerland), 14, 13102(2014), DOI: $10.3390 / \mathrm{s} 140713102$

19. C. O. Chey, Z. H. Ibupoto, K. Khun, O. Nur\& M. Willander, Sensors (Switzerland), 12, 15063(2012), DOI: $10.3390 / \mathrm{s} 121115063$.

20. G. K. Mishra, A. Sharma, K. Deshpande \& S. Bhand, Appl. Biochem. Biotechnol., 174, 998(2014), DOI: $10.1007 / \mathrm{s} 12010-014-0985-0$

21. F. Ismail \& S. B. Adeloju, Sensors, 10, 2851(2010), DOI: 10.3390/s100402851

22. S. Huang, F. Luo, and X. Lai, Asian J. Chem., 26, 6787(2014),DOI: 10.14233/ajchem.2014.16795

23. Z. H. Ibupoto, S. M. U. A. Shah, K. Khun\& M. Willander, Sensors, 12, 2456(2012),DOI: $10.3390 / \mathrm{s} 120302456$

24. S. Elhag, Z. H. Ibupoto, O. Nur\& M. Willander, Sensors (Switzerland), 14, 1654(2014),DOI: 10.3390/s140101654

25. J. Sánchez \& M. del Valle, Critical Reviews in Analytical Chemistry, 35, 15(2005),DOI: 10.1080/10408340590947899

26. A. M. Khedr, H. M. A. Shawish, M. Gaber\& K. I. A. Almonem, J. Surfactants Deterg., 17, 183(2014), DOI: 10.1007/s11743-013-1498-5

27. I. W. Mwangi, J. Catherine Ngila\& P. Ndungu, Water SA, 38, 707(2012),DOI: 10.4314/wsa.v38i5.8

[RJC-5143/2018] 